\title{
Morphometric and genetic analyses of diversity of the Lena horse (Equus lenensis Russanov, 1968; Mammalia: Equidae)
}

\author{
Natalia N. Spasskaya*, Igor Ya. Pavlinov, Fedor S. Sharko, \\ Eugenia S. Boulygina, Svetlana V. Tsygankova, Artem V. Nedoluzhko, \\ Gennady G. Boeskorov, Evgeny N. Mashchenko
}

\begin{abstract}
A pilot study of E. lenensis was carried out based on a small sample using a) standard morphometrics of the axial skull, mandible, the upper and lower cheek teeth; b) geometric morphometrics of the enamel crown patterns of the 1st upper and lower molars; c) molecular phylogenetic analysis with the complete mitochondrial genome sequencing. A certain morphological heterogeneity of $E$. lenensis by mostly dental and partly cranial characters was revealed. The study shows a necessity to reconsider species allocation of some records of Pleistocene horses in North East Siberia, and to carry out large-scale comprehensive revision of these materials using new approaches.
\end{abstract}

How to cite this article: Spasskaya N.N., Pavlinov I.Ya., Sharko F.S., Boulygina E.S., Tsygankova S.V., Nedoluzhko A.V., Boeskorov G.G., Mashchenko E.N. 2021. Morphometric and genetic analyses of diversity of the Lena horse (Equus lenensis Russanov, 1968; Mammalia: Equidae) // Russian J. Theriol. Vol.20. No.1. P.82-95. doi: 10.15298/rusjtheriol.20.1.09.

KEY WORDS: Equus lenensis, Pleistocene, North East Eurasia, morphology, geometric morphometrics.

Natalia N. Spasskaya[equusnns@mail.ru], I.Ya.Pavlinov[ipvl2008@mail.ru] Zoological Museum of Lomonosov Moscow State University, Bolshaya Nikitskaya Str. 6, 125009 Moscow, Russia; Fedor S. Sharko [fedosic@gmail.com] Institute of Bioengineering, Research Center of Biotechnology of the Russian Academy of Sciences, 119071 Moscow, Russia; National Research Centre "Kurchatov Institute", Akademika Kurchatova Sq. 1, 123098 Moscow, Russia; Eugenia S. Boulygina, Svetlana V. Tsygankova, National Research Centre "Kurchatov Institute”, Akademika Kurchatova Sq. 1, 123098 Moscow, Russia; Artem V. Nedoluzhko [nedoluzhko@gmail.com], Faculty of Biosciences and Aquaculture, Nord University, 8049 Bodø, Norway; Gennady G. Boeskorov [gboeskorov@mail.ru], Academy of Sciences of Sakha (Yakutia) Republic, Prospect Lenina 33, 677007 Yakutsk, Russia; Evgeny N. Mashchenko [evmash@mail.ru], Borissiak Paleontological Institute Russian Academy of Sciences, Profsojuznaya St., 123, 117647 Moscow, Russia; Academy of Sciences of Sakha (Yakutia) Republic, Prospect Lenina 33, 677007 Yakutsk, Russia.

\section{Морфометрический и генетический анализ изменчивости ленской лошади (Equus lenensis Russanov, 1968; Mammalia: Equidae)}

\author{
Н.Н. Спасская*, И.Я. Павлинов, Ф.С. Шарко, Е.С. Булыгина, \\ С.В. Цыганкова, А.В. Недолужко, Г.Г. Боескоров, Е.Н. Мащенко
}

РЕЗЮМЕ. Пилотное (на небольшой выборке) исследование E. lenensis проведено с применением a) стандартной морфометрии осевого черепа, нижней челюсти верхних и нижних щёчных зубов; б) геометрической морфометрии структуры зубной коронки 1-го верхнего и нижнего коренных; в) молекулярно-филогенетического анализа на основе секвенирования полного митохондриального генома. Выявлена определённая морфологическая разнородность E. lenensis по пропорциям черепа и зубов и по структуры зубной коронки коренных. Исследование показало необходимость пересмотра видовой принадлежности некоторых находок плейстоценовых лошадей Северо-Восточной Сибири и проведения широкомасштабной комплексной ревизии этих материалов с использованием новых подходов.

КЛЮЧЕВЫЕ СЛОВА: Equus lenensis, плейстоцен, Северо-Восточная Евразия, морфология, геометрическая морфометрия.

* Corresponding author 


\section{Introduction}

During the Pleistocene and the beginning of the Holocene, the horses (genus Equus) were among most abundant members of the megafauna in North East Eurasia; currently, they account for about 27 percent of all the remains of large mammals that were excavated and/or thawed from permafrost (Lazarev, 2008). Therefore, detailed exploration of their taxonomic diversity based on diversity of data and contemporary methodical approaches is essential for understanding temporal dynamics of faunal complexes of that region. However, information on their species diversity and geographical distribution is still very incomplete. Several forms were described (Rusanov, 1968), which were recognized subsequently as distinct species (Lazarev, 1980) supposedly having been replacing each other in time: the Early Pleistocene E. coliemensis Lazarev, 1980 and E. nordostensis Russanov, 1968, the Middle Pleistocene E. orientalis Russanov, 1968, and Late Pleistocene E. lenensis Russanov, 1968). The ranges of rather local E. coliemensis and E. nordostensis partially overlapped, and E. orientalis and E. lenensis seemed to be distributed much wider than their predecessors (Lazarev, 1980).

Unfortunately, a definitive analysis of taxonomic status of the above species and their distribution in both time and space is quite problematic because their diagnostic characters are not discrete, and geological ages of their type specimens were not identified precisely in most cases, save for E. lenensis (Belolyubsky et al., 2008). In the species delimitation of the Pleistocene horses in North East Siberia, the experts were usually guided by the general stratigraphy of the respective localities and, to a large extent, by general size of the horses decreasing in the order of $E$. nordostensis E. coliemensis - E. orientalis $-E$. lenensis. At present time, all remains of the fossil horses from the Late Pleistocene and the Early Holocene of North East Siberia are usually classified as E. lenensis. However, a preliminary visual examination of the materials (primarily skulls) indicated their apparent morphological heterogeneity. This provided a certain reason to make the following assumptions.

From the one hand, a geographically widespread and long existing species, currently identified as E. lenensis, was either extremely variable geographically or actually represented a flock of several close allospecies. From the other hand, several horse species could occur sympatrically in the region under consideration during the Pleistocene. This supposition presumes that the Pleistocene species of horses of North East Siberia could be distributed much wider both in time span and geographical distribution than it is currently believed. With respect to E. lenensis, it was known to have persisted not only until the early Holocene, but also up to the historical time in some local refugia (Kuznetsova et al., 2001; Schirrmeister et al., 2002). Besides, it seems plausible to suppose that some species of the North American caballoid horses could have spread locally to
North East Siberia during the Late Pleistocene, which might be especially true for E. lambei Hay, 1917. At last, a Pleistocene horse morphologically different from $E$. lenensis discovered in the region recently (Spasskaya et al., 2012) is to be mentioned.

These considerations make it quite reasonable to initiate a thorough exploration of the diversity of the Pleistocene horses in North East Siberian and eventually in a more widespread region.

Herewith, provided are the most important results of our pilot study of morphological and genetic differentiation of E. lenensis and several other morphologically similar Pleistocene to Holocene horses. Our main task was to analyze heterogeneity of the materials identified as E. lenensis using a combination of several quantitative methods, including standard and geometric morphometrics of craniodental characters and mitochondrial DNA sequencing.

\section{Material and methods}

A pilot status of our study was caused by a limited amount of the material involved in it (Appendix 1; the specimens IDs provided in the text are also given there). In addition to our main object $E$. lenensis, the materials on the following Pleistocene horse species were included in the sample: E. latipes Gromova, 1949; E. uralenlis Kuzmina, 1975; E. dalianensis Zhow, Sun, Xu, Li, 1985, and E. lambei. Besides; limited data on the modern E.c. przewalskii Poljakov, 1881 and several Siberian native breeds of E. ferus caballus Linnaeus, 1758 were also included to widen the factual basis of our comparisons. The species allocation of the studied specimens was adopted according to the original identifications by their collectors. The individual age of all specimens was identified as more than 5 years based on standard criteria of the teeth (Dyurst, 1936). The sets of species and specimens, for which respective morphometric materials were available, were differed because of the specifics of the fossil materials. Therefore, the following six blocks of morphometric data were analyzed separately: linear measurements of the axial skull and mandible, linear measurements of the upper and lower cheek teeth, the crown enamel patterns of the 1 st upper and lower molars.

For a number of specimens of E. lenensis, radiocarbon age was determined (five of them were dated in 2019), the range varied from 20000 to more than $47000 \mathrm{BP}$ (see Appendix 1).

The materials studied on each species, together with their sources and designations adopted herewith, are indicated in the Appendix 1.

For the morphometric analyses, the entire sample was arranged as follows. To identify taxonomic differences by the skull and dental measurements, three main groups were separated: E. lenensis, E. przewalskii, and $E$. $f$. caballus, each included 6 to 15 specimens. The subsamples designed for the analysis of dental crown patterns, included also a few specimens of $E$. lambei and single specimens per each of E. nordostensis, 
E. coliemensis, E. orientalis, E. latipes, E. uralenlis, and E. dalianensis. As the morphometic data were processed independently within each of the above-indicated six blocks, the overall number of the analyzed itmes exceeds the real number of individuals in our sample, as it is characterized in the Appendix 1.

For the present analysis of the mitochondrial genome, a specimen of E. lenensis (PIN No 3913/70) was sequenced because of peculiarities of its lower molars crown pattern: its double knot shape was similar to that of E. lambei. A complete mitochondrial genome obtained previously for another specimen of $E$. lenensis (PIN 301/1, MN187571; Nedoluzhko et al., 2020) was included in this study. The following specimens were also used for the phylogenetic reconstruction based on the coding sequences (CDS) of the mitochondrial genome: two specimens of $E$. cf. lambei from the Yukon Peninsula (KT168318.2; KT168322.2); several specimens of Equus (Equus) sp. from the Yukon Peninsula (KT757763.1), from the Taimyr Peninsula (CGG10022; CGG10023), from the middle reaches of the river Yana (KT368725.1); the specimens of the modern horse E. f. caballus (KT368726.1; NC 001640.1) and E. przewalskii (NC 024030.1); specimens of Equus kiang Moorcroft, 1841 (HM118851.1) and Equus asinus Linnaeus, 1758 (KX683425) were constituted an outgroup for the rooting of molecular phylogenetic tree.

For the standard morphometric analyses, we used 40 linear measurements of the axial skull, 15 measurements of the mandible, 24 measurements of the upper cheek teeth, 31 measurements of the lower cheek teeth, all taken according to the standard schemes (Eisenmann et al., 1988) by a standard caliper from the museum specimens. In 8 specimens of $E$. lenensis with partially damaged skulls, the empty cells in the tables with measurements were filled with the average values of respective characters calculated for this species; the total number of such substitutions ranged from 2 to 9 cells per 24 to 31 characters in total.

For the geometric morphometric analyses, the outline points were used to describe the enamel crown patterns of the 1st upper and lower molars (M1 and m1) (on this method, see Mitteroecker \& Gunz, 2009; Zelditch et al., 2012; Vasiliev et al., 2018). These outlines were set on the photos taken either from the museum specimens or, in the case of teeth of several extinct taxa, from their pictures in respective publications (listed in the Appendix 1). The general outlines of the teeth were described by 100 points each, and the fossett outlines on the upper molars were described by 50 points each. Terminology for the elements of the dental crowns was adopted after Eisenmann et al. (1988).

Since the samples characterized by different sets of characters did not coincide, morphometric analyses was performed independently for each of the six data blocks indicated above. In the case of cranial and dental standard characteristics, the original linear measurements were used as variables in all comparisons. In the case of the dental crown patterns, first, $x-y$-coordinates of the outline points were transformed into coefficients of the Fourier rows (or ellipses) by the Elliptical Fourie Analisis (EFA), with 20 harmonics calculated, and second, principal components (PCs) were extracted from these coefficients to be used as variables in the comparisons. An effectiveness of describing the tooth crown outlines this way was shown in a number of studies (Renaud et al., 2009; Labonne et al., 2014).

We estimated contributions of the species and age differences to the overall morphological disparity in the sample using one-way analysis of variance (ANOVA). The contribution in question was measured as a total ratio of the sums of squares corresponding to the explained and random variances for all variables in the given analysis (on this measure, see Pavlinov et al., 2008; Pavlinov, 2011). The ANOVA was also used to evaluate individual contributions of the particular variables to the species differences by the $F$ test, these estimates were used for selection of the variables for the subsequent discriminant function analysis (DFA)

Overall disparity structure in the sample, for each of the data block, was analyzed by the multidimensional scaling (MDS) based on the matrices of correlation distances between the specimens. The analyses were based on visual estimations of distributions of the specimens in the spaces of the 1st and 2d MDS axes.

The differences between the specimens with respect to their supposed taxonomic differentiation by the morphometric variables were explored using DFA. For each of the data block, we included all variables with the significance level $(p)$ of the $F$ criterion not exceeding 0.4 , as it was estimated preliminary by ANOVA, with no additional selection of those variables by the DFA algorithm being applied. This approach allowed us to maximize the differences being analyzed, with the threshold set empirically based on the minimal ( $F$ to remove) criterion built into the DFA. The differences in question were evaluated by Mahalanobis distances (DM); their values were considered within each of the data blocks because of the differences in number of variables in them. The above three species were used as a teaching sample, combined distributions of all specimens were then analyzed in the spaces of the 1st and $2 \mathrm{~d}$ canonical variables (CVs) obtained by the DFA for the respective data blocks.

Computations on the morphometric data were performed using the following programs. Outline points were set in the tpsDig2 (Rohlf, 2015). The EFA and PCs extraction were performed in the PAST (Hammer et al., 2001). Most of the other calculations were performed in the software package Statisctica for Windows (StatSoft, 2014).

Ancient DNA (aDNA) extraction from the bone powder was conducted in aDNA facilities of the National Research Center "Kurchatov Institute" (Moscow, Russia), using the methodology described by L. Orlando with colleagues (Orlando et al., 2013). DNA library for sequencing was constructed using Ovation Ultralow Library System V2 (NuGEN, USA), according the manufacturer's protocol. The final library was quantified by a high-sensitivity chip on a 2100 

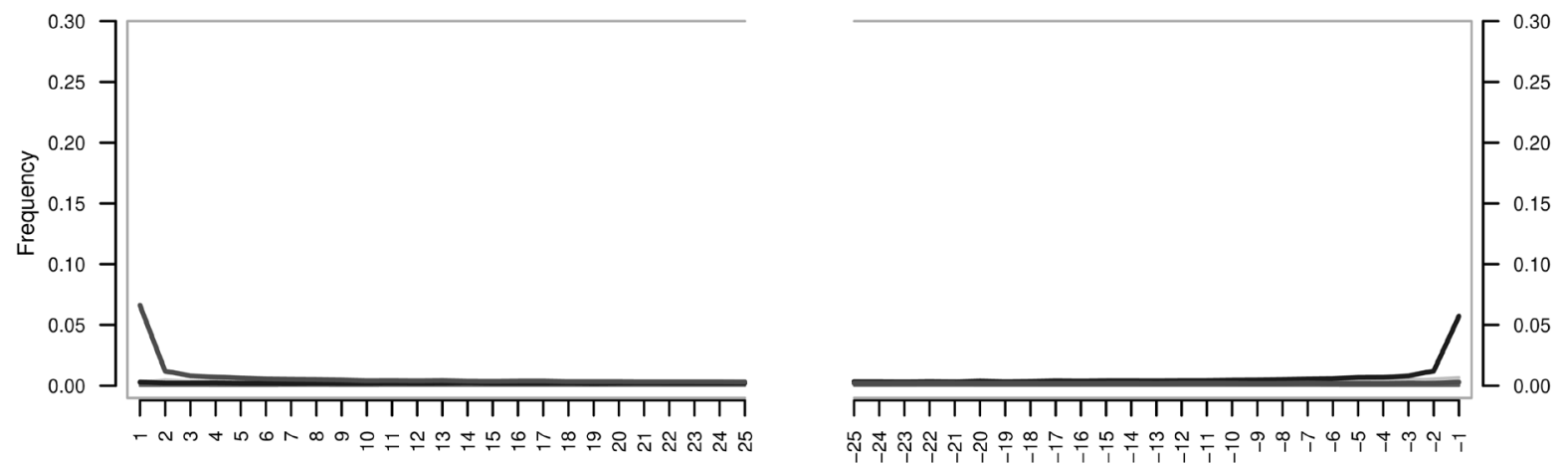

Fig. 1. Contamination test of DNA from the specimen of E. lenensis (PIN 3913/70) by the modern genetic material.

Bioanalyser instrument (Agilent Technologies, USA) and was sequenced on the Illumina NovaSeq6000 (Illumina, USA) platform with 150 base pairs paired-end reads.

In total, 183397565 paired-end reads were generated for PIN № 3913/70 E. cf. lenensis DNA-library. Illumina reads were filtered by PALEOMIX pipeline (Schubert et al., 2014) with mapDamage2 tool (Jonsson et al., 2013). This pipeline allows to perform reads quality filtering, adapter trimming, mapping to reference genome, and ancient DNA postmortem cytosine deamination marks identification (Schubert et al., 2014). E.f. caballus reference mitochondrial genome sequence (NC_001640.1, assembly EquCab3.0) and Bowtie 2 aligner under the "very-sensitive" and "rescale" options were used for analysis. Only PALEOMIX filtered reads (586) that contained specific to ancient DNA postmortem cytosine deamination patterns were used for E. lenensis (PIN № 3913/70) whole mitochondrial DNA assembly (MN187576). The model postmortem DNA damage from nucleotide misincorporation patterns is presented in Fig. 1. The phylogenetic relationships were reconstructed using Maximum likelihood analysis was conducted using RAxML (Stamatakis et al., 2008).

\section{Results}

Analyses of the cranial and dental measurements

Interspecific differences in the linear measurements revealed by ANOVA are most significant for the cheek teeth, especially the upper ones: the ratio of the explained variance equals to $40.4 \%$ for the upper and to $23.7 \%$ for the lower teeth, while it equals to $20.6 \%$ for the axial skull and only to $17.2 \%$ for the mandible. These figures indicated that conclusions about species allocations of the Pleistocene and modern horses, based on the cranial (especially mandibular) measurements can be very unreliable.

Comparison of the three main groups (E. lenensis, E. przewalskii, E.f. caballus) by the linear measurements of their axial skulls showed the following (Fig. 2). In the space of the first two MDS axes (Fig. 2A), E. lenensis overlapped largely with E.f. caballus, while E. przewalskii took a separate position, though without an evident hiatus. Among E. lenensis, the specimens GM DPMGI 1715, DPMGI 5059, IPM 2437 took a somewhat remote position relative to others. The DFA did not provide a clear separation of these three groups (Fig. 2B); with this, $E$. lenensis and $E$. przewalskii appeared to be most distinct $(\mathrm{DM}=114.8)$, while the differences between the former and $E$. f. caballus were minimal $(\mathrm{DM}=32.0)$.

The results of comparison of these groups by the mandible characters were somewhat different (Fig. 2C, D). In the space of the first two MDS axes (Fig. 2C), E. lenensis occupied an intermediate position between E. przewalskii and E. f. caballus, with the specimens GM DPMGI 6730 and PIN 3491/70 grouping with the former and the specimens GM DPMGI 3750 and IPM 2539 tending to be close to the latter. The DFA did not reveal any separation of these groups (Fig. 2D); contrary to the analysis of the axial skull, in the given case the differences are greatest between E. przewalskii and E.f. caballus $(\mathrm{DM}=20.6)$, while the differences of E. lenensis from them are less (DM $=7.8-11.3)$.

Comparison of E. lenensis, E. przewalskii, and E. $f$. caballus by their cheek teeth measurements showed the following (Fig. 3). In the space of the first two MDS axes defied by the upper teeth (Fig. 3A), they were distributed without an apparent hiatus: E. lenensis and E.f. caballus form a combined cloud, with a compact cloud of $E$. przewalskii adjacent to them. The overlapping zone of these groups included the specimen of E. orientalis (GM DPMGI 4612) and one of two E. coliemensis (KU-12), while the type specimen of the latter (GM DPMGI 1741) took a remote position. The group of E. lenensis showed a clear heterogeneity: GM DPMGI 3607 was situated close to E. przewalskii, while GM DPMGI 3715 and PIN $4223 / 72$ were distinct. The DFA clearly distinguished the three main groups, with $E$. lenensis being the least specific (Fig. 3B); the DMs between it and two other groups were 81.0-89.8, while between E. f. caballus and E. przewalskii it was 165.6. A separate position was occupied by E. orientalis and the type specimen of E. coliemensis, with the latter's second specimen (KU12) belonging evidently to E. lenensis.

The results by MDS for the lower cheek teeth (Fig. 3C) were in general similar to those for the upper ones; 

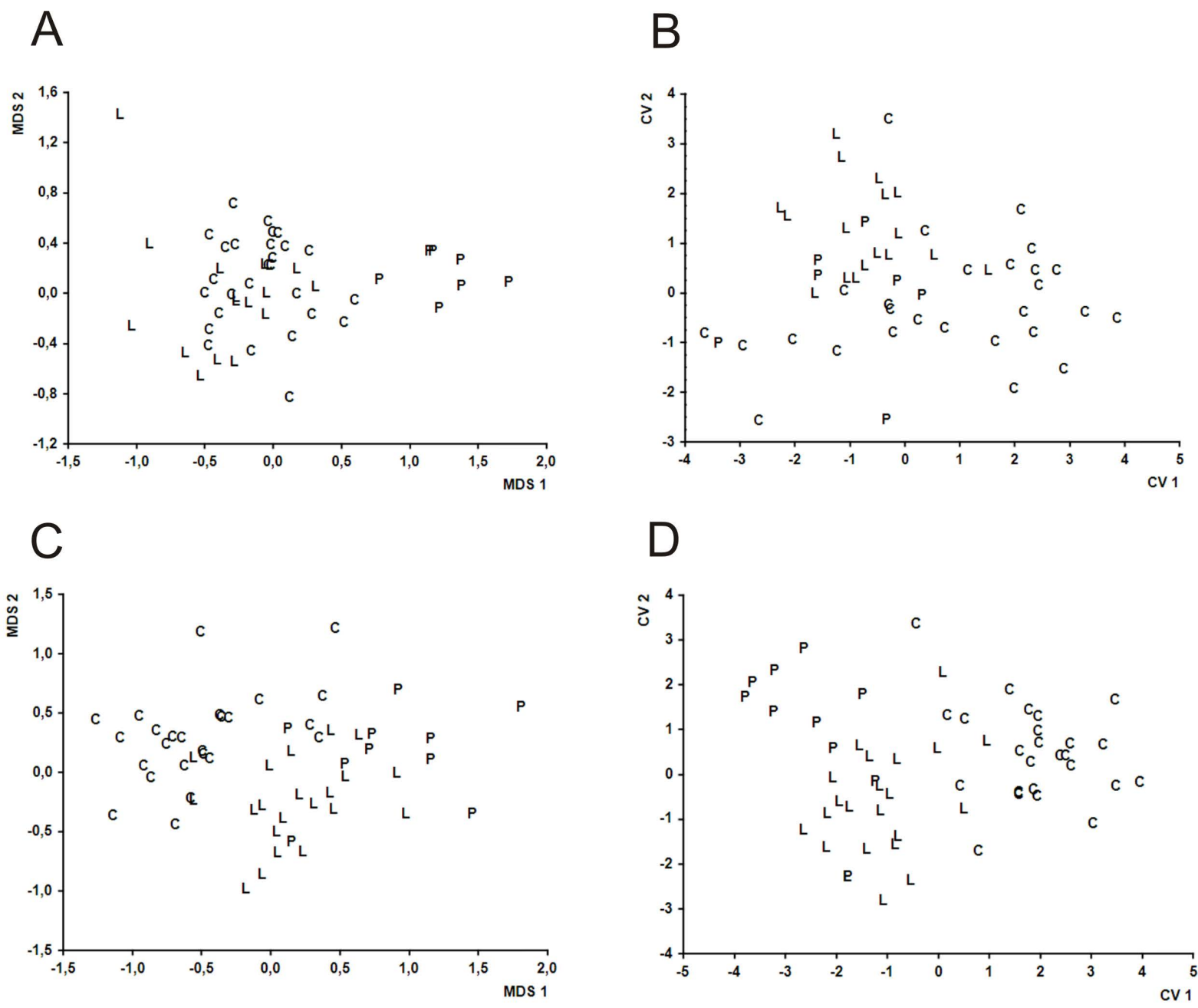

Fig. 2. The result of analyses of the horses based on the measurements of the axial skull (A, B) and mandible (C, D): distribution of specimens along the first two axes of the multidimensional scaling MDS 1, MDS 2 (A, B) and the first two canonical variables $\mathrm{CV} 1, \mathrm{CV} 2(\mathrm{C}, \mathrm{D})$ is shown. Designations of species: $\mathrm{C}-$ E. f. caballus, $\mathrm{L}-$ E. lenensis, $\mathrm{P}-$ E. przewalskii.

E. lenensis overlapped significantly with $E$.f. caballus and even to a greater extent with E. przewalskii. However, several specimens of E. lenensis (PIN 301/133, PIN 301/135, PIN 3491/70) appeared to be rather specific with respect to the rest. The specimens of E. coliemensis, E. orientalis, and E. nordostensis were distributed within the general cloud. The DFA clearly separated the main three groups (Fig. 3D), but unlike for the upper teeth, here E. lenensis was the most specific: the DMs between it and two other groups were 418.8-555.2, and between E. f. caballus and E. przewalskii it was 238.2. As to the $E$. coliemensis, its type specimen occupied a quite separate position, with another one being grouped with $E$. lenensis. At last, two specimens of $E$. orientalis were separated both from each other and from other horses, though both were situated close to E. lenensis.

The craniodental measurements most correlated with the 1st MDS axis and thus most significant for the uncovering heterogeneity of E. lenensis are listed in the Appendix 2 .
The results of analyses of differences among Pleistocene and modern horses by cranial and dental measurements, exposed above, can be summarized as follows.

1. In general, the dental traits were shown by ANOVA to have a greater diagnostic value for the species discriminations than the cranial ones, with the upper dentition measurements appeared to be the most and the mandibular once the least significant.

2. Significant distinctness of E. przewalskii with respect to $E$. lenensis and $E$.f. caballus (native breeds) by craniodental measurements was shown.

3. A group of specimens identified as E. lenensis was distinguished as clearly separated by the DFA, but this result should not be taken for a decisive evidence of its morphological compactness. This is because it is a principal function of DFA to make a priory classified groups as distinct and compact as possible, which is especially true for the small samples, as in our case. With this respect, quite important seemed 

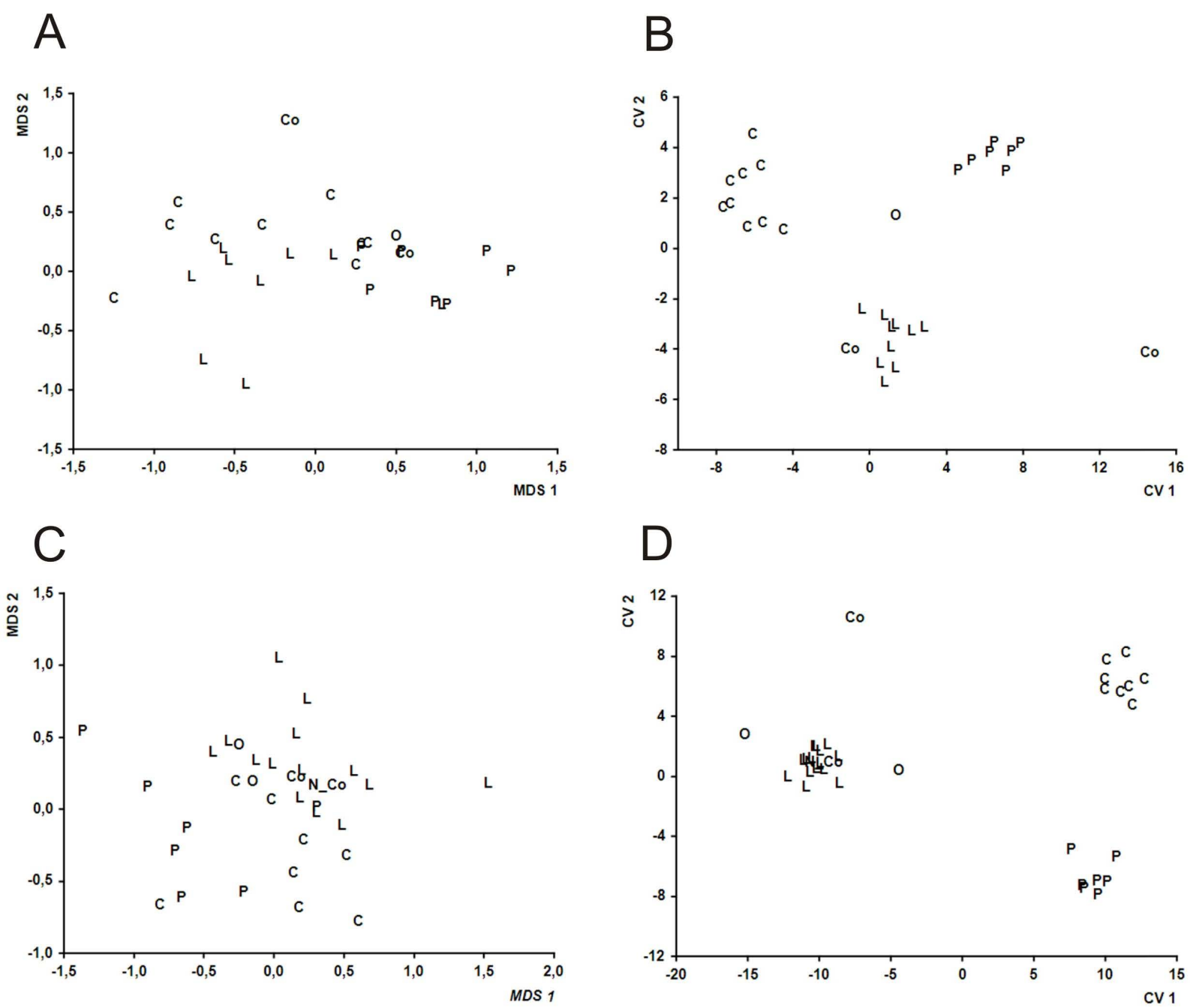

Fig. 3. The result of the analyses of the diversity of horses based on the measurements of the upper (A, B) and lower (C, D) cheek teeth: distribution of specimens along the first two axes of the multidimensional scaling MDS 1, MDS 2 (A, C) and the first two canonical variables CV 1, CV 2 (B, D). Designations of the species of the three main groups as in Fig. 2, designations of other species: $\mathrm{Co}-$ E. coliemensis, $\mathrm{N}-$ E. nordostensis, $\mathrm{O}-$ E. orientalis.

to be results of the MDS that showned this group to be heterogeneous by forming a rather loose "cloud", with several, though vague subgroups distinguishable in it. Craniodental measurements most significant for uncovering heterogeneity of $E$. lenensis were identified for subsequent analysis on a more extensive material.

4. The similarity relations of the specimens identified previously as members of distinct horse species E. coliemensis, E. orientalis, and E. nordostensis did not agree with any of their previous taxonomic allocations. For example, the specimen GM DPMGI 648 had been first designated as a paratype of E. orientalis by Rusanov (1968), allocated subsequently to E. coliemensis by Lazarev (1980) and then to E. nordostensis by Belolyubsky et al. (2008); according to the results of our analyses, it was grouped with E. lenensis. The specimen KU-12 was previously allocated to E. coliemensis, but it was shown above to differ significantly from the latter's type specimen and to group with $E$. lenensis.
Analyses of the dental crown patterns

The results of the analyses of species and age differences by ANOVA were as follows. As in the case of linear measurements, the portion of species differences in the overall disparity of the crown patterns was higher for the upper tooth than for the lower, 50.1\% and $31.2 \%$, respectively. The portion of age differences is significantly less, $9.0 \%$ and $6.0 \%$ for upper and lower tooth, respectively.

The regions of the greatest variability in the enamel structure of the crown of the 1 st molars were identified (Fig. 4). On the upper tooth (Fig. 4A), they were located between mesostyle and metastyle on the external part of the enamel outline, along the anterior and posteriors edges of the protocone, as well as in region of pli paraconule in the prefossette. On the lower tooth (Fig. 4B), shapes of the inner part of preflexid, the entoconid, and ectoflexid appeared to be most variable. 
A
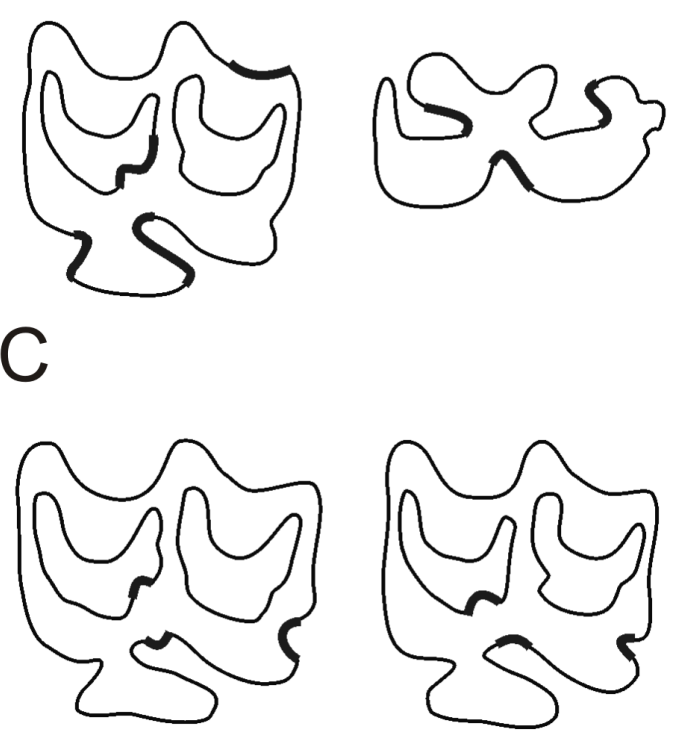

Fig. 4. Enamel crown patterns of the upper (A) and lower (B) first molars in the horses described by the outline points method; the consensus configurations of the crown patterns in the subgroups of E. lenensis (C). Bold lines indicate the areas with the greatest contributions to the overall differences.

Distribution of the specimens in the space of the $1 \mathrm{st}$ and $2 \mathrm{~d}$ MDS axes for the upper molar had the following features (Fig. 5A). The groups of E. przewalskii and $E$. lambei were quite compact, while E. lenensis and E. f. caballus were more dispersed, and E. f. caballus overlapped significantly with E. przewalskii and partly with E. lenensis. The latter's specimens appeared to be divided into four small subgroups, with some falling into E. przewalskii, some into E. lambei, several being combined with $E$. coliemensis, others united with specimens of E. uralensis and E. f. caballus. Single specimens of E. latipes, E. uralensis, and E. dalianensis fallen into a common cloud with $E$. przewalskii, several with E.f. caballus and with one subgroup of E. lenensis. According to the DFA (Fig. 5B), the specimens of E. lenensis, E. f. caballus and E. przewalskii formed virtually a single cloud, with the specimen of E. latipes falling into it. A small group of E. lambei was clearly separated from this cloud. The specimens of each of $E$. coliemensis and E. uralensis took isolated positions, while $E$. dalianensis was placed between $E$. lenensis and E. lambei.

Distribution of the E. lenensis specimens, taken separately, in the space of the 1st and 2d MDS axes for the upper molar indicated their dividing into two subgroups (Fig. 6). One of the latter included the specimens GM DPMGI 33 (type specimen), GM DPMGI 33/82, GM DPMGI 1715, GM DPMGI 3607, another included the specimens GM DPMGI 3750, PIN 301/1, PIN 4223/72,
ZIN 28825, IAM F-195, IAM F-2530. The consensus configurations of the tooth crown pattern calculated for these subgroups (Fig. 4B) indicated that they differed from each other by the shape of hypocone, inner portion of the prefosette, and inner portion of the postprotoconal groove.

Distribution of all the specimens in the space of the $1 \mathrm{st}$ and $2 \mathrm{~d}$ MDS axes for the lower molar was a kind of a vague cloud, with $E$. lenensis being decomposed into two groups (Fig. 5B). According to the DFA (Fig. 5G), E. przewalskii formed a rather compact group adjoining a relatively compact group of E. lenensis, the latter incorporating also E. uralensis. The distribution of $E$. f. caballus turned out to be very dispersed, with some of them fitting into E. lenensis. Among the remaining species, the position of $E$. orientalis was most distinct. It is to be noticed that initially supposed similarity of the specimen PIN 3913/70 of E. lenensis to E. lambei by its lower molar crown pattern (see Introduction) was not approved by the DFA.

The most significant results of the analyses of the crown patterns of the M1 and $\mathrm{m} 1$ can be summarized as follows:

1. Age-related variation (very worn teeth not included) of the tooth crown patterns was shown to be rather low, so it might be possible not take it in consideration in the explorations of species differentiation of the Pleistocene and modern horses;

2. Taxonomic differences in the crown pattern were shown to be more significant for the upper molar than for the lower;

3. E. lenensis and E. lambei were shown to be distinct in some dental features revealed by the DFA and less so in the dental features revealed by the MDS;

4. E. lenensis was shown to be morphologically heterogeneous by the upper molar crown patterns. According to the DFA, it could be divided into four subgroups combining with some other horse species. According to the MDS, when considered separately, it could be divided into two subgroups;

5 . The areas of the enamel outlines most affecting the overall disparity of the dental crown patterns, as revealed by the geometric morphometrics, did not coincide with the crown elements traditionally used for delimitation of the Pleistocene horse species. For the upper molars, the most attention was usually paid to the shape, size and inclination of the protocone relative to the axis of the tooth, and to the width of the inner (postprotocol) valley. For the lower molars, differences in the shape of the so called double knot, length and shape of preflexide and postflexid, and the location of isthmus were traditionally considered the most pronounced.

\section{Analysis of the mitochondrial genomes}

This study represents the comparative analysis of two whole mitochondrial genomes of E. lenensis. The mitochondrial genome of the specimen of E. lenensis (PIN № 301/1, MN187571) specimen has been described previously (Nedoluzhko et al., 2020). The mitochondrial 
A
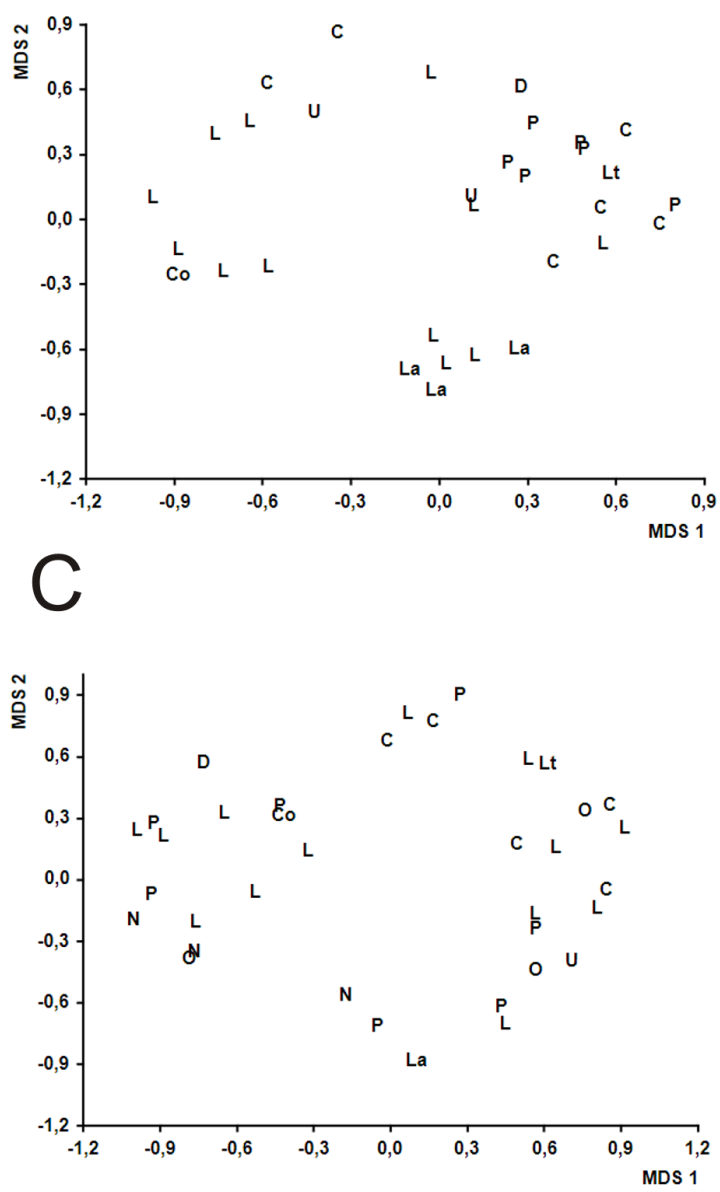
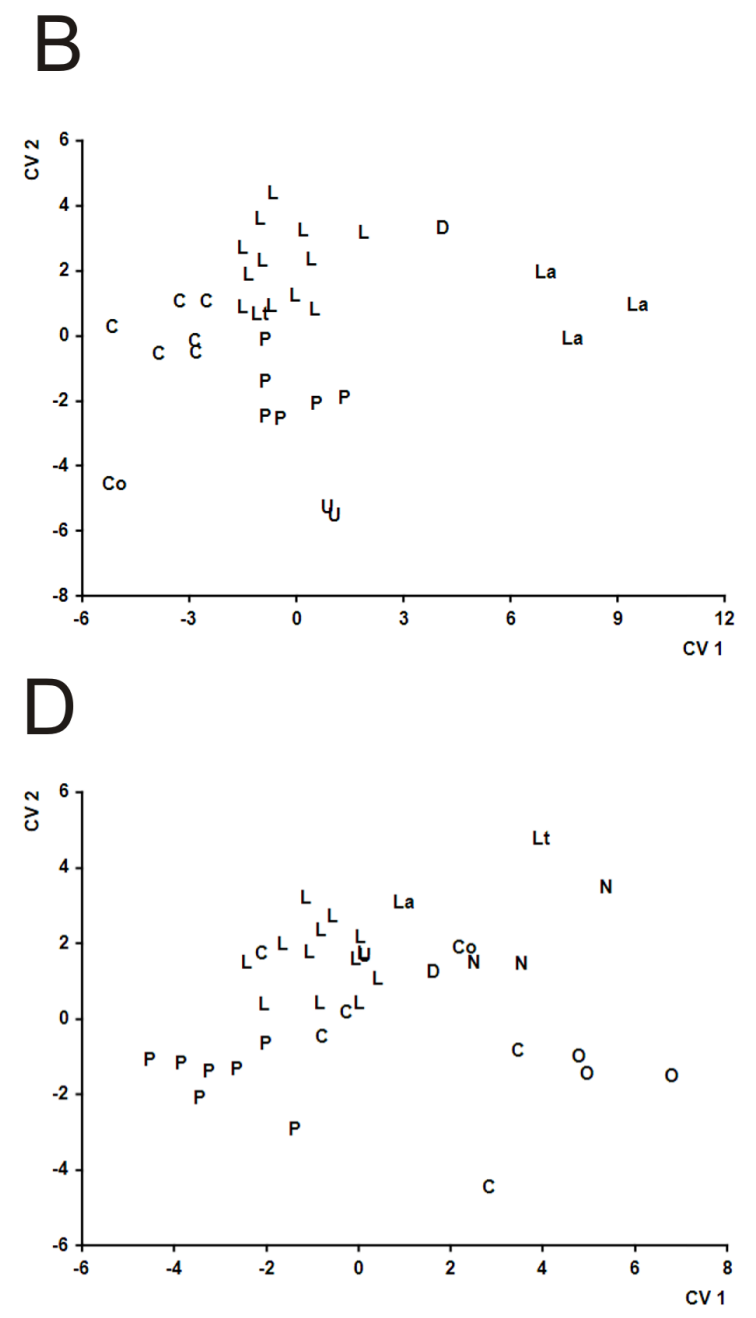

Fig. 5. The result of the analysis of the diversity of the enamel pattern of the 1 st upper (A, B) and lower (C, D) molars in horses: the distribution of specimens along the first two axes of multidimensional scaling $(\mathrm{A}, \mathrm{C})$ and the first two canonical variables (B, D). Designations of species as in Figs. 2 and 3, designations of other species: D - E. dalianensis, La - E. lambei, Lt E. latipes, $\mathrm{U}-$ E. uralensis.

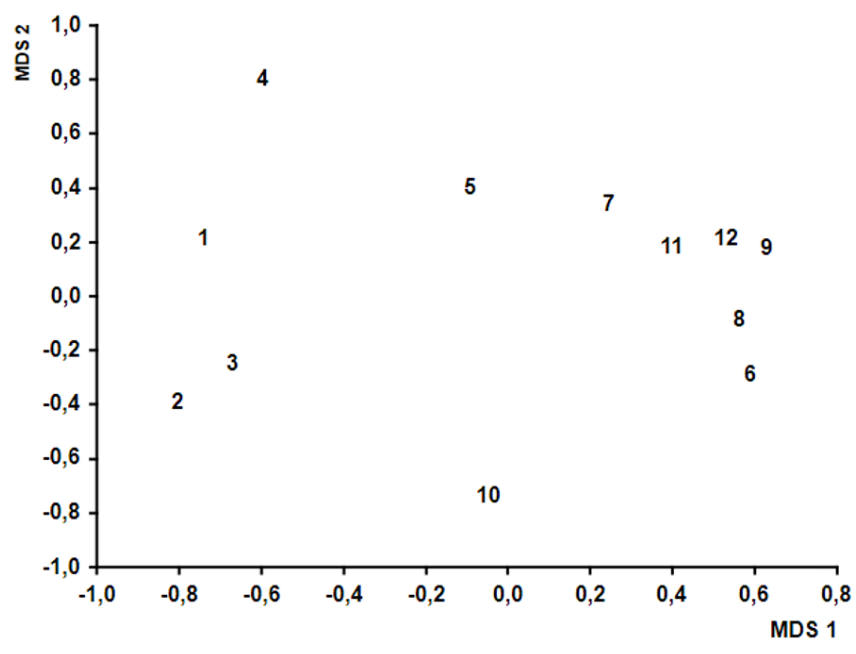

Fig. 6. Distribution of the specimens of E. lenensis along the first two axes of the multidimensional scaling according to the enamel crown pattern of the 1st upper molar. 


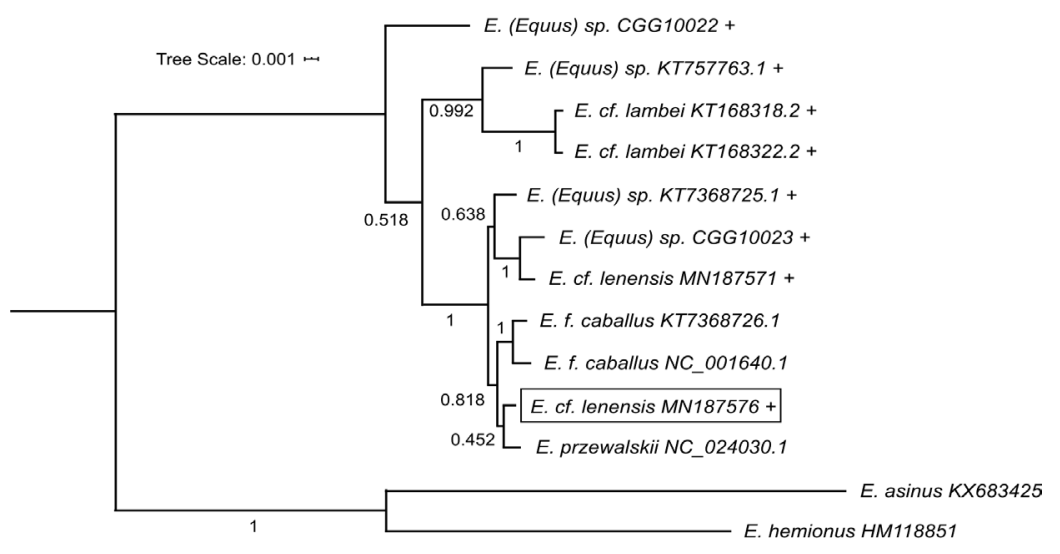

Fig. 7. Maximum likelihood phylogenetic tree of E. lenensis and several other species based on their CDS. Pleistocene specimens are marked with crosses, E. lenensis specimen PIN 3913/70 is highlighted with a rectangle. Figures on the branches indicate bootstrap support.

genome of the E. lenensis (PIN № 3913/70) specimen, that had specific traits in enamel structure of the crown of the lower molars, was analyzed for first time (MN187576).

Results of our phylogenetic analysis of the CDS of the mitochondrial DNA sequences of E. lenensis (MN187571 and MN187576) together with E. lambei and three other Pleistocene horses (Fig. 7) did not show any clear subdivision of the former into any subgroups compatible with those revealed by the morphometric analyses. This result might indicates either a genetic uniformity of this entire group or a poor resolution of this marker for discriminating its subgroups. We suppose that a more indeep paleogenomic analyses of the nuclear DNA would allow us to explore the history of E. lenensis and related taxa of the Beringia region.

\section{Discussion}

Taxonomic structure of the Pleistocene caballoid horses of North East Eurasia is still very debatable. Morphological heterogeneity of the materials on them was repeatedly shown, but lack of a precisely dated large enough sample did not allow to revise already recognized and to describe new taxa (Vangengeim, 1961; Sher, 1971). Validity of some species, which descriptions were based on very limited number of specimens from different localities was actively disputed, which was true, in particular, for E. orientalis (Sher, 1971). Morphological evidence for acknowledging species status of E. lenensis was presented by B.S. Rusanov (1968), P.A. Lazarev (1980; Lazarev \& Tomskaya, 1987), I.E. Kuzmina (1997). P.A. Lazarev (1980, Tables 1, 3-5) divided the cranial material on $E$. lenensis he studied into two geographically defined groups from Western and East Yakutia; their average sizes were somewhat different, but this point was not discussed in his work. Subsequently, the issues of intraspecific morphological variation of $E$. lenensis, including its possible correlation with geographical factors, were not discussed. However, even a cursory examination of limited materials on this species indicated certain differences in sizes and proportions of the skull, dentition, shape of the 1st molars, etc. An analysis of all such materials was complicated by the lack of clear morphological diagnostic features for the Late Pleistocene horses of North East Siberia, as well by the lack of a representative sample of the AMS-dated material.

Our pilot study, although based on a quite limited data, makes it possible to point out some important results to be taken in consideration in the further research, they are briefly discussed below.

It was shown that the species delineation of the Siberian Pleistocene horses, as they were identified in previous studied, by cranial measurements only was not reliable enough. Instead, linear measurements and enamel patterns of the cheek teeth, especially upper ones, appeared to be much more informative for this purpose. Due to this, previous species allocation of a number of specimens studied by us was shown to be incorrect, so its reconsideration based on the dental characters is needed.

Disagreement between the dental crown elements used traditionally for delimitation of the horse species and revealed by the geometric morphometrics deserves clarification. One probable cause is that in the formalized approach we used, the mutual displacements of all parts of the teeth are ascribed an equal weight and evaluated simultaneously, regardless of whether the variations are intraspecific or interspecific. In contrast, in the traditional studies, experts used to analyze these two levels of variation separately based on a priori species allocation. However, the differences they used to interpret taxonomically significant might in fact reflect 
but some aspects of the morphological disparity not directly related to the taxonomic diversity. Therefore, further exploration of more dental materials, based on an independent reliable method of species delimitation, is needed to uncover those dental crown elements that actually allow to discriminate species.

Morphological heterogeneity of $E$. lenensis, together with some other close species, revealed by us was not clear-cut; separate analyses of the data blocks with isolated axial skulls, mandibles, and teeth provided different groupings of the specimens allocated to it. An evident cause of this inconsistency is that these morphological structures are but weakly correlated and thus yield different similarity relations. That was probably why we failed to uncover any evident geographical factors correlated with such kind of morphological heterogeneity. Therefore, in order to make the latter more explicit, the next step of exploration of the Late Pleistocene horses of North East Siberia should incorporate the data on as many complete specimens as possible.

All these inconsistencies, both "outer" (with previous studies) and "inner" (within our study), clearly indicate that an extensive development (more materials) of further explorations in caballoids should be completed with an "intensive" one (more advanced multivariate statistical methods). With this, special attention is to be paid to a correct combination of different methodologies allowing for cross-validation of the results they provide. For instance, the MDS carries out an analysis of the structure of diversity without prior recognition of any groups; besides, it's being based on a decomposition of distance matrix makes it more appropriate for the exploration of small samples, unlike nowadays more popular principal component analysis (PCA) based on correlation matrix. As to the DFA, it allows to analyze diagnostic features of priory defined groups, to evaluate posterior probabilities of allocation of the specimens to them, and to compare results of different prior groupings to see which one is most adequate to the structure of the overall diversity revealed by the MDS.

Molecular methods may have good prospects for taxonomic studies of the Pleistocene materials on the horses (Weinstock et al., 2005; Orlando et al., 2008, 2013; Librado et al., 2016). Work with the mitochondrial genomes from North East Siberia is just at its beginning (our study, as well as Nedoluzhko et al., 2020). Full nuclear genomes have been obtained so far only for three specimens, one was a Holocene horse from the Yana River basin - Batagai, radiocarbon age $4400 \pm$ 35 uncal. yBP (Gr 50842) (Librado et al., 2015); other two were Pleistocene horses from Taimyr: CGG10022 $42692 \pm 891$ BP(UBA-16478); CGG10023 - $16099 \pm$ 192 BP(UBA-16479) (Schubert et al., 2014b). However, morphological descriptions of respective materials on them have not been made and, accordingly, it is not possible to allocate these genetically dated specimens to known species. As to our materials, they also do not allow to discuss an issue of concordance between genetic and morphometric data with respect to the species delineation. Thus, there is currently no any adequate conjoint morpho-genetic analysis of the taxonomic diversity of the caballoid horses of North East Eurasia.

A similar conclusion is true for the Pleistocene horses of North America, where 10 to 40 species were recognized dependent on different data and methods (Azzaroli, 1998). Genetic studies (mitochondrial control region HVR1) have questioned such a rich species diversity of those horses. Based on the genetic and morphological (metapodial bones) data, only two lines were identified, namely non-caballoid stilt-legged and caballoid stout-legged horses, each probably represented by few species (Weinstock et al., 2005; Heintzman et al., 2017). In the light of new data, debatable appeared to be not only validity of some species but also their belonging to the group of caballoid horses, which may be true, in particular, for E. lambei (Burke \& Cinq-Mars, 1996). An integrated approach using genetic analysis in conjunction with standard and geometric morphometric analyses showed a great perspective of such synthesis, making it possible to clarify taxonomic status and relationships of various forms in the genus Equus (Barrón-Ortiz et al., 2017).

We did not touch in this study any particular questions concerning species systematics of the Siberian horses because of an evident shortage of the studied materials. However, our results indicated that the future taxonomic studies based on the analyses of more specimens, including the type material, should not limit themselves to the traditional skeletal materials but include the dental crown patterns, as well. With this, special attention should be paid to the taxonomic differentiation of the populations now allocated to the E. lenensis and its most close allies.

\section{Conclusions}

The results presented in this paper demonstrated a good perspective for using new characters and methods to solve certain taxonomic problems in groups of the Pleistocene and modern horses of North East Eurasia. This pilot research revealed the following most important points.

Using geometric morphometrics, the most variable areas of the molar crown patterns were identified, which differ from those traditionally used in the caballoid taxonomy. A possibility of incorporating them in the taxonomic studies of the horses will need further examination based on more materials and adequate methods.

The use of nuclear genomes is needed for a better understanding of the level of genetic variation and phylogenetic relationships of Pleistocene horses in North East Eurasia and North West North America.

A certain heterogeneity of the E. lenensis group in dental and partly cranial features was confirmed. But a small sample of material did not allow us a more accurate description of the identified groups and to associate them with certain spatial or temporal factors. 
A necessity of reconsidering species allocation of some materials and, in the future, a large-scale comprehensive revision of the Pleistocene horses of the North-East of Siberia was shown.

Over the past 40 years, an extensive new paleontological material has been accumulated and its amount continues to grow, partly due to global climate change. The need for a comprehensive large-scale taxonomic revision of the genus Equus of North East Eurasia and North West North America is obvious. It should be based on a joint analysis of more extensive both morphological and genetic materials, in the first case using a set of the modern morphometric methods.

ACKNOWLEDGEMENTS. The authors are sincerely grateful to curators for the access to respective museum collections: F.K. Shidlovsky \& I.V. Kirillova (Ice Age Museum), G.F. Baryshnikov \& M.V. Sablin (Zoological Institute RAS) и I.N. Belolybsky (Geological Museum of the Diamond and Precious Metals, Geology Institute SB RAS). Very useful comments on the early draft of this paper by A.Yu. Puzachenko (Institute of Geography, RAS), Ch.I. Barrón-Ortiz (Royal Alberta Museum), and an anonymous reviewer are highly appreciated.

The research was conducted as a part of Scientific project of the State Order of the Government of Russian Federation No. 121032300105-0 implemented by the Research Zoological Museum at Lomonosov Moscow State University.

This work was carried out using high performance computing resources of the Federal Center for collective usage at NRC "Kurchatov Institute" (RFMEFI62114X0006, http://computing.kiae.ru). This work was partially carried out in Kurchatov Center for Genome Research and supported by Ministry of Science and Higher Education of Russian Federation, grant No. 075-15-2019-1659. The funders had no role in study design, data collection and analysis, decision to publish, or preparation of the manuscript.

\section{References}

Azzaroli A. 1998. The genus Equus in North America: the Pleistocene species // Paleontographia Italica. Vol.85. P.1-60.

Barron-Ortiz C.I., Rodrigues A.T., Theodor J.M., Kooyman B.P., Yang D.Y. \& Speller C.F. 2017. Cheek tooth morphology and ancient mitochondrial DNA of late Pleistocene horses from the western interior of North America: Implications for the taxonomy of North American Late Pleistocene Equus // PLoS ONE. Vol.12. No.8. e0183045.

Belolybsky I.N., Boeskorov G.G., Sergeenko A.I. \& Tomshin M.D. 2008. [Catalogue of quarternary mammals collection from the Geological Museum of the Diamond and Precious Metals Geology Institute, SB RAS]. Yakutsk: YaNC SO RAN. 204 p. [in Russian].

Burke A. \& Cinq-Mars J. 1996. Dental characteristics of late Pleistocene Equus lambei from the Bluefish Caves, Yukon Territory, and their comparison with Eurasian horses // Geographie physique et Quaternaire. Vol.50. No.1. P.81-93.
Dyurst U. 1936. [Exterior of the Horse]. Moscow-Leningrad: Sel'khozgiz. 344 p. [in Russian].

Eisenmann V., Alberdi M.T., de Giuli G. \& Staeche U. 1988. Studying fossil horses. V.1: Methodology // Collected papers after the "New York International Hipparion Conference, 1981”. Leiden; New York; KØbenhavn; Köln: E.J. Brill Editorship. 71 p.

Hammer Ø., Harper D.A.T. \& Ryan P.D. 2001. PAST: Paleontological Statistics Software package for education and data analysis // Palaeontologia Electronica. Vol.4. No.1.9 p.

Harington C.R. \& Clulow F.V. 1973. Pleistocene Mammals from Gold Run Creek, Yukon Territory // Canadian Journal of Earth Sciences. Vol.10. P.697-759.

Heintzman P.D., Zazula G.D., MacPhee R.D.E., Scott E., Cahill J.A., McHorse B.K., Kapp J.D., Stiller M., Wooller M.J., Orlando L., Southon J., Froese D.G. \& Shapiro B. 2017. A new genus of horse from Pleistocene North America // eLife. Vol.6. e29944.

Jonsson H., Ginolhac A., Schubert M., Johnson P.L. \& Orlando L. 2013. mapDamage2.0: fast approximate Bayesian estimates of ancient DNA damage parameters // Bioinformatics. Vol.29. No.13. P.1682-1684.

Kuzmina I.E. 1997. [Horses of North Eurasia from the Pliocene till the present time] // Trudy ZIN RAS. Vol.273. 233 p. [in Russian].

Kuznetsova T.V., Sulerzhitsky L.D., Siegert Ch. 2001. New data on the "Mammoth" fauna of the Laptev Shelf Land (Arctic Siberia) // Proceedings of the First International Congress “The World of Elephants". Rome. 16-20 October 2001. P.289-292.

Kuznetsova T.V., Van der Plicht H. 2009. [Late Pleistocene and Holocene horses of Northern Yakutia] // 200 let otechestvennoy paleontologii. Materialy vserossiyskogo soveschaniya. 20-23 October 2009. Moscow: PIN RAS. P.65-66. [in Russian].

Labonne G., Navarro N., Laffont R., Chateau-Smith C., Montuire S. 2014. Developmental integration in a functional unit: Deciphering processes from adult dental morphology // Evolution and Development. Vol.16. No.4. P.224-232.

Lazarev P.A. 1980. [Anthropogenic horses of Yakutia]. Moscow: Nauka. 190 p. [in Russian].

Lazarev P.A. 2008. [Large mammals of the anthropogen of Yakutia]. Novosibirsk: Nauka. 160 p. [in Russian].

Lazarev P.A. \& Tomskaya A.I. 1987. [Mammals and biostratigraphy of the late cenozoic of Northern Yakutia]. Yakutsk: Institut geologii i geophisiki SO AN SSSR. 170 p. [in Russian].

Librado P., Der Sarkissian C., Ermini L., Schubert M., Jónsson H., Albrechtsen A., Fumagalli M., Yang M.A., Gamba C., Seguin-Orlando A., Mortensen C.D., Petersen B., Hoover C.A., Lorente-Galdos B., Nedoluzhko A., Boulygina E., Tsygankova S., Neuditschko M., Jagannathan V., Thèves C., Alfarhan A.H., Alquraishi S.A., Al-Rasheid K.A.S., Sicheritz-Ponten T., Popov R., Grigoriev S., Alekseev A.N., Rubin E.M., McCue M., Rieder S., Leeb T., Tikhonov A., Crubézy E., Slatkin M., Marques-Bonet T., Nielsen R., Willerslev E., Kantanen J., Prokhortchouk E. \& Orlando L. 2015. Tracking of the origins of Yakutian horses and the genetic basis for their fast adaptation to Subarctic environments // PNAS. Vol.112. No.50. E6889-E6897. 
Librado P., Fages A., Gaunitz C., Leonardi M., Wagner S., Khan N., Hanghøj K., Alquraishi S.A., Alfarhan A.H., Al-Rasheid K.A., Der Sarkissian C., Schubert M. \& Orlando L. 2016. The evolutionary origin and genetic makeup of domestic horses // Genetics. Vol.204. No.2. P.423-434.

Mitteroecker P. \& Gunz P. 2009. Advances in geometric morphometrics // Evolutionary Biology. Vol.36. No.2. P.235-247.

Nedoluzhko A.V., Sharko F.S., Boulygina E.S., Tsygankova S.V., Slobodova N.V., Gruzdeva N.M., Rastorguev S.M., Spasskaya N.N., Maschenko E.N., 2020. The complete mitochondrial genome of the extinct Pleistocene horse (Equus cf. lenensis) from Kotelny Island (New Siberian Islands, Russia) and its phylogenetic assessment // Mitochondrial DNA. Part B. Vol.5. No.1. P.243-245.

Orlando L., Ginolhac A., Zhang G., Froese D., Albrechtsen A., Stiller M., Schubert M., Cappellini E., Petersen B., Moltke I., Johnson P.L.F. , Fumagalli M., Vilstrup J.T., Raghavan M., Korneliussen T., Malaspinas A.-S., Vogt J., Szklarczyk D, Kelstrup C.D., Vinther J., Dolocan A., Stenderup J., Velazquez A.M.V,, Cahill J., Rasmussen M., Wang X., Min J., Zazula G.D., Seguin-Orlando A., Mortensen C., Magnussen K., Thompson J.F., Weinstock J., Gregersen K., Røed K.H., Eisenmann V., Rubin C.J., Miller D.C., Antczak D.F., Bertelsen M.F., Brunak S., Al-Rasheid K.A.S., Ryder O., Andersson L., Mundy J., Krogh A., Gilbert M.T.P., Kjær K., Sicheritz-Ponten T., Jensen L.J., Olsen J.V., Hofreiter M., Nielsen R., Shapiro B., Wang J., Willerslev E. 2013. Recalibrating Equus evolution using the genome sequence of an early Middle Pleistocene horse // Nature. Vol.499. No.7456. P.74-78.

Orlando L., Male D., Alberdi M.T., Prado J.L., Prieto A., Cooper A. \& Hänni C. 2008. Ancient DNA clarifies the evolutionary history of American late Pleistocene equids // Journal of Molecular Evolution. Vol.66. No.5. P.533-538.

Pavlinov I.Ya. 2011. Morphological disparity: An attempt to widen and to formalize the concept // Pavlinov I.Ya. (Ed.). Research in biodiversity: Models and applications. InTech Open, Rejeka. P.341-364.

Pavlinov I.Ya., Nanova O.G. \& Spasskaya N.N. 2008. Toward exploration of morphological disparity of measurable traits of mammalian skull. 1. Interrelation between different forms of group variation // Zhurnal Obschei Biologii. Vol.69. No.5. P.453-459 [in Russian, with English summary].

Reimer P.J., Bard E., Bayliss A., Beck J.W., Blackwell P.G., Ramsey C.B. Buck C.E., Cheng H., Edwards R.L., Friedrich M., Grootes P.M., Guilderson T.P., Haflidason H., Hajdas I., Hatté C., Heaton T.J., Hoffmann D.L., Hogg A.G., Hughen K.A., Kaiser K.F., Kromer B., Manning S.W., Niu M., Reimer R.W., Richards D.A., Scott E.M., Southon J.R., Staff R.A., Turney C.S.M., van der Plicht J. 2013. IntCal13 and Marine13 Radiocarbon Age Calibration Curves 0-50 000 Years cal BP // Radiocarbon. Vol.55. No.4: IntCal 13. P.1869-1887.

Renaud S., Pantalacci S., Quéré J.-P., Laudet V., Auffrayd J.-C. 2009. Developmental constraints revealed by co-variation within and among molar rows in two murine rodents // Evoluiton and Development. Vol.11. No.5. P.590-602.

RohlfF.J. 2015. The tps series of software // Hystrix, the Italian Journal of Mammalogy. Vol.26. No.1. P.9-12.

Rusanov B.S. 1968. [Biostratigraphy of the cenozoic sediments of Southern Yakutia]. Moscow: Nauka. 459 p. [in Russian]. Schirrmeister L., Siegert Ch, Kuznetsova T., Kuzmina T., Andreev A.A., Kienast F., Meyer H. \& Bobrov A.A. 2002. Paleoenvironmental and paleoclimatic records from permafrost deposits in the Arctic region of Northern Siberia // Quaternary International. Vol.89. P.97-118.

Schubert M., Ermini L., Der Sarkissian C., Jonsson H., Ginolhac A., Schaefer R., Martin M.D., Fernandez R., Kircher M., McCue M., Willerslev E., Orlando L. 2014a. Characterization of ancient and modern genomes by SNP detection and phylogenomic and metagenomic analysis using PALEOMIX. Nature Protocole. Vol.9. No.5. P.1056-1082.

Schubert M., Jónssona H., Chang D., Der Sarkissian C., Ermini L., Ginolhac A., Albrechtsen A., Dupanloup I., Foucal A., PetersenB., Fumagalli M., Raghavan M., Seguin-Orlando A., Korneliussen T.S., Velazquez A.M.V., Stenderup J., Hoover C.A., Rubin C.-J., Alfarhan A.H., Alquraishi S.A., Al-Rasheid K.A.S., MacHugh D.E., Kalbfleisch T., MacLeod J.N., Rubin E.M., Sicheritz-Ponten T., Andersson L., Hofreiter M., Marques-Bonet T., Gilberta M.T.P., Nielsen R., Excoffier L., Willerslev E., Shapiro B. \& Orlando L. 2014b. Prehistoric genomes reveal the genetic foundation and cost of horse domestication // PNAS. E5661-E5669.

Sher A.V. 1971. [Mammals and stratigraphy of the Pleistocene of the extreme northeast of the USSR and North America]. Moscow: Nauka. 310 p. [in Russian].

Spasskaya N.N., Kuznetsova T.V. \& Sher A.V., 2012. Morphometric study of the skull of a Late Pleistocene mummy of the Bilibino horse from the Western Chukchi Peninsula // Paleontological Journal. Vol.46. No.1. P.92-103.

Stamatakis A., Hoover P. \& Rougemont J. 2008. A rapid bootstrap algorithm for the RAxML Web servers // Systematic Biology. Vol.57. No.5. P.758-771.

StatSoft Inc. 2014. STATISTICA (Data Analysis Software System), Version 12.

Vangengeim E.A. 1961. [Paleontological substantiation of stratigraphy of anthropogenic deposits of the North of East Siberia] // Trudy GIN AN SSSR. Vol.48. 182 p. [in Russian].

Vasil'ev A.G., Vasil'eva I.A. \& Shkurihin A.O. 2018. [Geometric morphometry: from theory to practice]. Moscow: KMK Scientific Press. 471 p. [in Russian].

Weinstock J., Willerslev E., Sher A., Tong W., Ho S.Y.W., Rubenstein D., Storer J., Burns J., Martin L., Bravi C., Prieto A., Froese D., Scott E., Xulong L. \& Cooper A. 2005. Evolution, systematics, and phylogeography of Pleistocene horses in the New World: A molecular perspective // PLoS Biol. Vol.3. e241.

Zelditch M.L., Swiderski D.L. \& Sheets H.D. 2012. Geometric morphometrics for biologists: A primer. 2nd ed. Amsterdam: Elsevier. 478 p. 
Appendix 1. Craniodental materials on the Pleistocene and modern Equus used in this research (species listed alphabetically).

E. coliemensis: GM DPMGI lower toothrow No 1721, upper toothrow No 1741 (type specimen E. coliemensis Lazarev, 1980), KU - upper toothrow (fig. 12).

E. dalianensis: $\mathrm{KU}$ - upper and lower toothrows (fig. 44).

E. f. caballus: Mongol bread (complete skulls): ZIN — Nos 5231, 18055, 18056, 18057, 18058, 18059 , 20137; ZMMU — Nos S-110476, S-110478, S-134563, S-163569, S-190395; UB - Nos 1, 2; Yakut bread (complete skulls): GM - Nos 4, 5, 8, 16, 33, 4693, 1931-32, 1932-34; ZIN Nos 4051, 15245, 31168; ZMMU — Nos S-181390, S-186091, S-186096, S-186097, S-186098; Tuva bread (axial skulls): ZMMU — Nos S-186099, S-197459, S-197460, S-197463.

E. lambei: HA - upper and lower toothrows (figs. 16, 17, 24).

E. latipes: KU - upper and lower toothrows (fig. 19).

E. lenensis: GM DPMGI - axial skull with toothrows Nos 33 (type specimen of E. lenensis Russanov, 1968), 33/82, 1715, 3715, 3607, 3750, 5059, 6730; mandible with toothrow Nos 3750, 4826, 6730; IAM - axial skull with toothrows Nos F-195, F-254, F-2431, F-2437, F-2442, F-2530; mandible with toothrow Nos F-649, F-2379, F-2436, F-2438, F-2539, F-2540, F-2541, F-2542, F-2543; KU - upper and lower toothrows (fig. 39); PIN - axial skull with toothrows 301/533, 301/1, 4223/72; mandible with toothrow Nos 3491/611, 3491/630, 3913/70, 301/133, 301/135, 301/540; ZIN axial skull with toothrows No 19031.

E. nordostensis: GM DPMGI - upper toothrow No 4659, lower toothrow Nos 92, 648, 6435.

E. orientalis: GM DPMGI - upper toothrow No 4612, lower toothrow Nos 152, 564, 1732, 3600.

E. przewalskii (complete skulls): AN - Nos 288/120, 374, 378, 1032, 1035, 1154, 1195, 2412; TGU — Nos 3525, 3526; ZIN — Nos 5212, 5213, 5214, 5216, 5218, 27089; ZMMU — Nos S-1772, S-115391, S-133806, S-187005.

E. uralensis: $\mathrm{KU}$ - upper and lower toothrows (figs. 28, 29).

Specimens with radiocarbon age determined:

\begin{tabular}{|c|c|c|c|c|}
\hline $\begin{array}{l}\text { Specimens } \\
\text { E. lenensis }\end{array}$ & $\mathrm{BP} *$ & $\begin{array}{l}{ }^{14} \mathrm{C} \text {, uncal. } \\
\mathrm{BP}(1 \sigma)\end{array}$ & $\begin{array}{c}\text { cal. BP } \\
\text { Radiocarbon Calibration Program } \\
\text { CALIB REV7.1.0** }\end{array}$ & Comments \\
\hline $\begin{array}{l}\text { GM DPMGI } \\
\text { No } 33\end{array}$ & $33560 \pm 250-230$ & & & $\begin{array}{l}\text { СгА-43065 } \\
\text { (Kuznetsova \& Plicht, 2009) }\end{array}$ \\
\hline $\begin{array}{l}\text { GM DPMGI } \\
\text { No } 3750 \\
\end{array}$ & $26340 \pm 140$ & & & $\begin{array}{l}\mathrm{C}_{\Gamma} \mathrm{A}-43060 \\
\text { (Kuznetsova \& Plicht, 2009) }\end{array}$ \\
\hline $\begin{array}{l}\text { GM DPMGI } \\
\text { No } 3607\end{array}$ & $2310 \pm 80$ & & & \begin{tabular}{|l|} 
LU-1084 \\
(Belolybsky et al., 2008)
\end{tabular} \\
\hline PIN No 301/1 & & $21105 \pm 55$ & $\begin{array}{l}68.3 \text { (1 sigma) } \\
25356-25566 \quad 1.000 \\
95.4(2 \text { sigma }) \\
25240-25642 \quad 1.000 \\
\text { Median Probability: } 25456 \\
\end{array}$ & IGAN/CIR UG6966 \\
\hline PIN No $301 / 533$ & & $19795 \pm 50$ & \begin{tabular}{|l}
$68.3(1$ sigma $)$ \\
$23724-23943 \quad 1.000$ \\
$95.4(2$ sigma $)$ \\
$23616-24043 \quad 1.000$ \\
Median Probability: 23833 \\
\end{tabular} & IGAN/CIR UG6969 \\
\hline PIN No $3491 / 630$ & & $39272 \pm 147$ & \begin{tabular}{|l}
68.3 (1 sigma) \\
$42861-43166 \quad 1.000$ \\
$95.4(2$ sigma $)$ \\
$42714-43324 \quad 1.000$ \\
Median Probability: 43017 \\
\end{tabular} & IGAN/CIR UG6971 \\
\hline PIN No 3913/70 & & $<46230$ & & IGAN/CIR UG6967 \\
\hline PIN No $3491 / 611$ & & $<46615$ & & IGAN/CIR UG6968 \\
\hline
\end{tabular}

* without specifying the type of date.

** Reimer et al., 2016.

Collection IDs:

AN - Research Museum, Biosphere Reserve "Askania Nova";

GM DPMGI - Geological Museum of the Diamond and Precious Metals, Geology Institute SB RAS;
HA - Harington \& Clulow (1973);

IAM — Ice Age Museum, Moscow, Russia;

KU - Kuzmina (1997);

PIN - Paleontological Institute RAS;

TGU - Zoological Museum, Tomsk State University; 
UB - State Agrarian Institute, Mongolia;

ZIN - Zoological Institute RAS;

ZMMU — Zoological Museum, Lomonosov Moscow State University.

Designations:

IGAN/CIR - Institute of Geography, Russian Academy of Sciences, Moscow, Russia / Center for Applied Isotope Studies, University of Georgia, Athens, USA;
Сг A - Centre for Isotope Research, Groningen University, Groningen, Netherlands;

LU - Laboratory of geomorphological and paleogeographic studies of the Polar Regions and Oceans V.P. Köppen, Leningradsky University (now - Saint Petersburg State University), Saint Petersburg, Russia.

Appendix 2. Craniodental measurements of E. lenensis most significant for analysis of its heterogeneity (see text for explanation).

\begin{tabular}{|c|l|c|c|c|c|c|}
\hline No & \multicolumn{1}{|c|}{ Measurements } & $n$ & M & $\min$ & $\max$ & SD \\
\hline 1 & Palathal breadth at P2 & 18 & 67.7 & 59.2 & 79.3 & 4.3 \\
\hline 2 & Choan width (maximum) & 16 & 41.4 & 35.4 & 48.2 & 3.5 \\
\hline 3 & Mastoid width & 17 & 118.8 & 110.5 & 129.5 & 4.6 \\
\hline 4 & Bazygomatic breadth & 17 & 202.9 & 188.8 & 212.5 & 6.9 \\
\hline 5 & Occipital height & 18 & 60.7 & 52.4 & 67.4 & 4.6 \\
\hline 6 & Mandibule length & 16 & 445.3 & 413.0 & 490.0 & 19.8 \\
\hline 7 & Lower cheek teeth total length & 17 & 176.8 & 162.2 & 198.5 & 10.7 \\
\hline 8 & Lower cheek teeth premolar length & 17 & 89.2 & 80.0 & 97.0 & 6.1 \\
\hline 9 & Mandible symphyse length & 17 & 89.3 & 74.5 & 111.5 & 9.9 \\
\hline 10 & Mandible height at ascending ramus & 16 & 207.7 & 186.2 & 222.5 & 9.5 \\
\hline 11 & Mandible height at condyle & 15 & 222.7 & 201.2 & 237.0 & 10.7 \\
\hline 12 & Breadth P2 & 16 & 25.9 & 22.0 & 30.8 & 2.3 \\
\hline 13 & Length protocone P2 & 8 & 10.1 & 7.0 & 12.2 & 1.8 \\
\hline 14 & Breadth P3 & 18 & 28.0 & 22.4 & 33.0 & 2.5 \\
\hline 15 & Length protocone P3 & 18 & 13.5 & 11.2 & 16.4 & 1.4 \\
\hline 16 & Breadth protocone P3 & 9 & 5.0 & 4.0 & 6.9 & 0.8 \\
\hline 17 & Length M1 & 18 & 24.1 & 20.4 & 30.2 & 2.1 \\
\hline 18 & Breadth M2 & 18 & 26.1 & 22.0 & 29.5 & 1.7 \\
\hline 19 & Breadth protocone M2 & 9 & 5.1 & 3.5 & 8.0 & 1.4 \\
\hline 20 & Breadth protocone M3 & 8 & 4.3 & 2.7 & 6.7 & 1.1 \\
\hline 21 & Breadth p2 & 17 & 16.3 & 14.0 & 19.3 & 1.4 \\
\hline 22 & Length double knot p2 & 9 & 14.9 & 11.5 & 17.0 & 1.8 \\
\hline 23 & Length postflexid p2 & 9 & 14.8 & 10.2 & 17.0 & 2.2 \\
\hline 24 & Length p3 & 9 & 18.1 & 24.5 & 31.0 & 1.5 \\
\hline 25 & Length double knot p3 & 13.6 & 13.0 & 18.3 & 1.6 \\
\hline 26 & Length postflexid p3 & 33.2 & 29.0 & 41.0 & 2.9 \\
\hline 27 & Length double knot p4 & & & 16.3 & 2.6 \\
\hline 28 & Length double knot m1 & 9.9 & 16.5 & 1.5 \\
\hline 29 & Length double knot m2 & 9.7 & 11.5 & 14.9 & 1.0 \\
\hline 30 & Length double knot m3 & 13.7 \\
\hline & & 9 & 12.4 & 16.2 & 1.2 \\
\hline
\end{tabular}

Designations: upper and lower molars: M1 and m1; upper and lower premolars: P1 and p1. 